\title{
Article \\ Jumping the Shark: White Shark Representations in Great White Serial Killer Lives-The Fear and the (Pseudo-)Science
}

\author{
Iri Cermak (D)
}

Independent Researcher, Hallandale Beach, FL 33009, USA; icermakresearch@protonmail.com

\begin{abstract}
Sharks are among the most endangered nonhuman animals on the planet because of industrial fishing, the shark meat and fin trade, expanding recreational fishing, and other anthropogenic causes. White sharks (Carcharodon carcharias), the most visible in popular culture, remain vulnerable (VU, IUCN Red List) and understudied, although population recovery is having a measure of success in regions like the Eastern Pacific and the Northern Atlantic of the United States. As numbers rise, Jaws associations also remain in vogue in programming that emphasizes human-wildlife ${ }^{* *}$ conflict such as Shark Week's Great White Serial Killer Lives. Network marketing typically promotes this content by hyping shark science. Textual analysis, however, suggests that exposure to pseudoscientific narratives and unethical fear-inducing images is counterproductive to wider support for conservation programs and public recognition for sharks' rights to their habitats.
\end{abstract}

Keywords: white sharks (Carcharodon carcharias); shark-human conflict; predators/carnivores and perceived threat; fear; science; pseudoscience; Jaws; media representation

Citation: Cermak, Iri. 2021. Jumping the Shark: White Shark

Representations in Great White Serial Killer Lives-The Fear and the (Pseudo-)Science. Journalism and Media 2: 584-604. https://doi.org/ 10.3390/journalmedia2040035

Academic Editors: Carrie P. Freeman and Núria Almiron

Received: 1 August 2021

Accepted: 22 September 2021

Published: 13 October 2021

Publisher's Note: MDPI stays neutral with regard to jurisdictional claims in published maps and institutional affiliations.

Sharks are captivating nonhuman animals who, like many of their terrestrial counterparts, are under threat of extinction from anthropogenic causes (Dulvy et al. 2017). Approximately 100 million sharks per year are taken by both legal and illegal commercial fisheries both for the shark meat and the shark fin trade (Hammerton and Ford 2018) and as a result of overfishing and by-catch (Cardeñosa et al. 2018; Ferretti et al. 2010). Increasing demand for consumer goods that range from pet food and cosmetics to vaccine adjuvants as well as booming recreational fishing are contributing to the depletion of these populations. Threats from plastic pollution (Environmental News Network 2020), mercury and arsenic toxicity (Barcia et al. 2020), ocean acidification and dead zones (Vidal 2004), dwindling refuges (Letessier et al. 2019), and other hazards also persist in their habitats. As apex carnivores who comprise over 500 species present on the planet for 420 million years, sharks regulate food webs, and their loss influences the functioning and resilience of marine ecosystems (Heupel et al. 2014).

The Sixth Mass Extinction (Steffen et al. 2007; Ceballos et al. 2015) continues to impact sharks at variable rates. Because habitats, morphology, and reproductive rates vary among species, broad sustainability criteria do not apply, even as the recovery of populations remains expedient. White sharks (Carcharodon carcharias), the most visible and popular in the media, are at globally vulnerable levels (VU), while the number of mature individuals continues to decrease (IUCN Red List 2020). Population distribution in most regions is also understudied because of the difficulty in investigating large migratory marine nonhuman animals even as technology continues to improve (Huveneers et al. 2018, p. 1). Despite that some areas like the Eastern Pacific and the Northwest Atlantic are seeing a relative population rebound (Guerra 2019, p. 369; Huveneers et al. 2018, p. 3), in most, figures continue to be modest, ranging from the $100 \mathrm{~s}$ to the $1000 \mathrm{~s}$, and risk of overexploitation remains high (Huveneers et al. 2018). In many others, data is limited, and reliable abundance indicators are lacking (Huveneers et al. 2018, pp. 2-3). As a pelagic species, white sharks are also in need of transnational protections in Exclusive Economic Zones (EEZ) and data on socio-economic and cultural indicators to enhance protections (Dulvy et al. 2017, p. R566). 
Despite an upsurge in human population (Rees 2020) and more people moving to or recreating on the coasts, negative shark-human interactions remain at low levels (International Shark Attack File 2019). Despite being low-probability, high-consequence events, private individuals, governments, and media scrutinize them by engaging negative emotions (Sunstein 2002, p. 84). Media treat these incidents as high-impact and high-affect, as well as newsworthy and saleable, due to their potential for dramatization as detrimental to human personal safety, property, economic viability, and recreational prerogatives (Guerra 2019, p. 369; Nyhus 2016). Although TV programs are meant to help fill the knowledge gap by delivering science in an entertaining fashion, media also remain focused on human-wildlife conflict with large sharks. Reliance on fear through gory reenactments of incidents and their scarring aftereffects minimizes science by way of pseudoscientific Jaws-like formulas (Neff 2015; Evans 2015, pp. 265-66; Metz 2008) that have transformed the white shark into a media cash cow (Parker 2016). This focus, moreover, displaces attention from the shark species and populations in urgent need of recovery (Shiffman et al. 2020) and negatively impacts public opinion and support for conservation and effective policy-making (Hardiman et al. 2020; Neff and Hueter 2013; Bornatowski et al. 2019, p. 34). It also fundamentally distracts from the vision that sharks have intrinsic rights to their habitats.

\section{Literature Review}

Media remain primary sources for the human manufacture of relations with nonhuman animals through narratives and imagery that speak to dominance and exploitation as normative social behaviors (Linné 2015, p. 58). Disparagement of apex species usually occurs when humans are outcompeted for shared space or resources (Ford and Hammerton 2020, p. 152). Human-wildlife conflict can therefore trigger intense emotions that hinge on mental representations of a species, beliefs about humans' place in the nonhuman world, and the degree of situational control that determines how much an individual is willing to cede to the survival of other species (Jürgens and Hacket 2021, p. 11).

Shark-human relations, however, are not monochromatic but diverse and contingent on both human and shark agencies. For humans with knowledge of the marine environment, shark experiences are highly individual and dependent on value-based relationships with both the ocean and its inhabitants (Gibbs 2020, p. 8). The nature of encounters can hinge on knowledge of species behavior during the day, night, or season; feeding patterns; prey occurrence; and visibility (Parletta 2019; Gibbs 2020, p. 10). Sharks are also known for their ease in attracting humans with their beauty, calm demeanor, curiosity, and even shyness (Gibbs 2020, pp. 9-10, 11-14). Since dramatic shark-human encounters accounted for as "attacks" make it into the official record while other kinds of experiences (positive or neutral) are excluded, what is reported is typically reshaped in media products through overemphasis on affect and unfavorable anthropomorphic projections that demonstrate a consistent negative bias toward sharks.

Studies show that media reporting is overwhelmingly driven by shark-on-human violence. A 2012 U.S. and Australian study on print media articles between 2000 and 2010, for example, showed that shark incidents, labeled "attacks", were featured over five times conservation and other concerns (Muter et al. 2013, p. 190). Implicit geographical bias detrimental to sharks has also been found to be common in the reporting of terrestrial versus aquatic human-wildlife conflict. Findings from a 2018 study revealed that in human-wildlife conflict media reports between 1875 and 2017, those from developed countries highlighted shark incidents 65 percent of the time, while, in developing countries, 90 percent focused on terrestrial human-wildlife conflict. Shark incidents in these reports were sensationalized as "attacks" (Bornatowski et al. 2019, pp. 33-34).

Media reportage also aggravates conflict by implying express calculation on the part of the shark through the use of labels like "vicious", "savage", "killer", and "monster" (Simmons and Mehmet 2018). An analysis of language in 310 articles on human fatalities during Western Australia shark encounters between August 2010 and April 2014 generated 
a direct linkage between "shark" and the value-laden term "attack" as well as associative terms like "man-eater", "rogue", "killer", "monster", "horror", "Jaws", and even "sighting" as prescriptive of risk (McCagh et al. 2015, pp. 274-75). A study of Facebook pages of Australian media-i.e., newspapers, television, and radio- also uncovered a similar emphasis on white sharks in threatening interactions with humans as well as recurrent use of the term "attack" along with mitigation and/or deterrents such as culling (Le Busque et al. 2019).

Post-incident accounts, for their part, also tend to exploit the language of crime to describe shark suspects as elusive by "giving authorities the slip" or fleeing the scene like a "fugitive from justice" (Peace 2015). Reports also further the impression that shark populations are rebounding and fast approaching the status of nuisance or vermin through references to a surge in incidents and a focus on their succession (Bornatowski et al. 2019, p. 34; Sabatier and Huveneers 2018; Miller 2003). These allegations not only imply that sharks are not as endangered but that they are potentially fair game for eradication.

Othering media discourses that demand vilification of sharks as apex species chiefly bank on fear (Ford and Hammerton 2020). These discourses amplify the perceived risk of being bitten and/or killed by a shark and influence social tolerance of these nonhuman species by exacerbating difficulties in managing their populations (Myrick and Evans 2014, pp. 547, 557; Guerra 2019, p. 370; Sabatier and Huveneers 2018, p. 338). Even mere exposure to media headlines about shark-human interactions has been found to amplify risk perception (Le Busque et al. 2021a). Fear amplification is pernicious because it aggravates perceived human-wildlife conflict, given that simply due to perceived harm, the greater the fear of the nonhuman animal or species, the higher the chance exists for his or her elimination (Guerra 2019, p. 369; Hammerton and Ford 2018; Ordiz et al. 2013; Le Busque et al. 2021a). Fear is also linked to short-term responses and lethal control policy-making regardless of the seriousness of events, the effectiveness of results, or the lack of public support for culling programs (Pepin-Neff and Wynter 2018a; Gibbs 2020, pp. 12, 15; McCagh et al. 2015, p. 276).

Studies show that fear is also the prime driver in the business of selling sharks to TV audiences, with the most recent viewing exacting the greatest anxiety (Myrick and Evans 2014, p. 559), likely due to the medium's ability to translate events into the present (Edgerton 2001, p. 3). Shark programming capitalizes on human fear to such an extent that a mere $60 \mathrm{~s}$ of background music in shark documentaries influences perceptions of the species as savage and violent, with visuals or without (Nosal et al. 2016, pp. 6, 11, 13). Participants in a survey on fear of sharks also predictably linked these nonhuman animals to large size, teeth, predatorial behavior, blood, danger, and death, as well as fear of the ocean and open-ocean swimming after drowning and water depth (Le Busque et al. 2021b, pp. 4-5). Despite sharks' status as some of the most endangered species in the world (Shiffman 2018), human fear of these nonhuman animals has come to drive what media about the species are produced, what kind of content is disseminated, and what messages are persistently communicated (Merskin 2018, p. 46).

\section{The White Shark in the Media: A Shark Is a Shark Is a Jaws Shark}

Of the small number of shark species involved in human-wildlife conflict, white sharks are the subject of the most trepidation and fascination and serve as template for sharks in popular culture. A Washington Post article points to the species' reputation as "media stars" and "silent assassins" and credits the feature release Jaws (Spielberg 1975) for their rescue from obscurity (Dunkel 2015). The film's commercial success and wide reach (Lundén 2012), which set the standard for white sharks as "rogue" nonhuman animals through the spectacle of fatal encounters (Francis 2012, pp. 47, 56), has also enabled monetization of their image by way of an ever-burgeoning repertory. A 2013 ABC News Nightline report aired in the U.S. counted no less than 50 films starring sharks as movie villains (Donovan and Morris 2013), a tally that a report three years later hiked to over 70 films (Brown 2016). Analysis of 109 shark movies on the Internet Movie Database 
(IMDb) also uncovered that, similar to news coverage, 96 percent of films featured sharks in pursuit of human prey that ended in death (Le Busque and Litchfield 2021). Speaking of the genre's commercial viability, senior box office analyst at Exhibitor Relations Jeff Bock noted that, because of their "primal pull" on audiences, these features are for the most part "inexpensive ... [to produce, and] provide fantastic bang for your buck ... " Comescore senior media analyst Paul Dergarabedian, for his part, echoed similar thoughts in describing the shark genre as "review-proof" and "one of the most resilient ... in all of film" (Katz 2019).

On TV, Discovery's Shark Week, marketed as "the prime showcase for all things shark" (Duhaime-Ross [2013] 2014), has carried the Jaws mantle since 1987 through documentaries, blood-in-the-water accounts, feature films, and celebrity-centered specials. While deemed to promote shark scientist exposure, the annual summer media event has also received its share of criticism for exaggerating the fear factor, twisting scientific research, and furthering false narratives about nonexistent marine creatures (Shiffman 2018; Wallace 2019).

Network executives and producers nonetheless continue to promote shark programming for contributing to the species' popularity and aiding conservation efforts (Stockton 2016). Jeff Kurr, director of the Air Jaws and Great White Serial Killer franchises noted in an interview that Shark Week programming has helped "make people aware that sharks ... have a lot of challenges" and that catching them is no longer acceptable (Cavanaugh 2020). Because these programs are meant to be partly educational, Shark Week content is usually plugged in the media by way of its scientific value. Executive VP of digital media Scott Lewers observed in a separate interview that "It's science first but mixed with entertainment" for audience engagement (Shiffman 2018). Kurr, for his part, has promoted his Great White Serial Killer franchise as based on "a lot of great information and a lot of great science ..." " and cited a study by Martin et al. (2009) on white shark hunting methods as inspiration (Cavanaugh 2020).

Early research on science in TV documentaries established that it is the result of two sets of parameters: fantasy and dramatization, on the one hand, and factual information and argument, on the other (Silverstone 1984, pp. 387-88). Rather than scientific veracity, however, producers of Hollywood entertainment aim to generate verisimilar images that conjure up scientific credibility while also invoking ambiguity and polysemic interpretations of "reality" (Frank 2003, pp. 428, 429, 447). Moreover, over the past 15 years, Discovery Network's factual entertainment has witnessed a gradual distancing from scientifically verifiable claims through the proliferation of techniques and forms of argumentation that have produced pseudoscience rather than science (Campbell 2016).

Shark Week programs have been flagged for their dependence on narrow and overdramatic Jaws representations, which cuts across documentary formats that subsume purportedly educational content (Lerberg 2016, p. 35). In an earlier interview, Kurr pointed to his Great White Serial Killer series as chronicling "the most intriguing shark attack story since Jaws. But unlike Jaws, this story is 100 percent true. It's about a series of mysterious great white attacks that we solve using the latest shark science" (Aitzen 2017).

Needless to say, detailing events by way of Jaws iconography, with its innate commodification of fear, is about "not knowing" sharks as much as arguably knowing anything about them for the way this imagery is clamped on incidents in an anthropocentric and culturally-dominant fashion (Fishman 1980). While metaphors are typically deployed to help audiences relate to science, to the extent that they are liable to be seen as factual, they are also incorrect (Kueffer and Larson 2014, pp. 720, 722). In addition, the Jaws formula renders sharks unilaterally responsible for human-wildlife conflict by way of three elements: the shark's intentionality behind the events, the shark's return to willfully strike again, and the shark's forcing of the human hand to "deal" with the situation by giving pursuit and entrapping (if not killing) him or her (Neff 2015, pp. 114, 123; Pepin-Neff and Wynter 2018b, p. 1). Rather than deploying specific language to describe the nature of the encounter (Pepin-Neff 2014) and examining variables such as visibility or anthropogenic causes, the Jaws analogy also enables conflation of all interactions under the term "attack", 
while prior to 1930 these incidents where designated as "shark accidents" (Pepin-Neff in Kraterou 2021).

Jaws iconography can also function as a "script" as it updates encounters through stereotypical usage and circumvents contestation when deployed as a passing mention across media formats (Van Dijk 1981, 1988). Moreover, recalling and stacking incidents by way of Jaws imagery generates a retroactive form of "shark frenzy" (Gibbs 2020, pp. 14-17) that assaults the public with fear and misinformation and is highly prescriptive in the way humans should interpret diverse shark experiences.

Because media are hard-pressed to speak of shark species in ways other than antagonistic Jaws-type discourses, this kind of pseudoscientific TV content poses a real risk to sharks for its potential persuasiveness when coupled with particular entertainment techniques and the objectivity-based claims common in documentary (Campbell 2016, p. 21). Due to science's high standing in film and TV programming, and efforts to overemphasize the scientific status of claims for the purpose of credibility, it is therefore necessary to examine this content for its potential impact on shark wellbeing, the species' rights to their habitats, and ongoing population recovery.

Campbell lists a number of criteria about pseudoscientific programs in factual enertainment that center on depictions of cryptids (Loch Ness, Bigfoot), ghost hauntings, and extraterrestrial visitors, which are useful when considering Jaws shark programming:

1. Statements about the "reality" of particular phenomena in these programs do not meet the standards of logic and evidence of established science due to their unrepeatability, weakness, or outright falsehood. In other words, to be viable, these statements would necessitate the rethinking of well-established science garnered through a rigorous process of observation, testing, and experimentation (Campbell 2016, pp. 188, 193; Sokal 2006, p. 288).

2. Visual communication of science is chiefly accomplished through superficial "accouterments" or "trappings", such as the enlisting of real scientists who supply samples or provide specimen analysis, insertion of lab imagery, and the use of technology, all of which attempt to ensure a measure of credibility for the pseudoscientific theories floated in the program (Campbell 2016, p. 193; Brewer 2012, p. 324).

3. Evidence collection and witness examination are usually performed by a two-person team invested in the research, who also engage in "fact-finding" missions yet fail to secure conclusive evidence to back up their claims. The team relies on uncontested interviewee statements as a form of witness testimony, which amounts to little more than anecdotal evidence. Given the lack of conclusive proof, the team's "discovery trips" also ultimately serve as nothing more than entertainment for themselves and the production crew.

4. A third party in the program functions in the role of skeptic. Yet, this individual is never allowed the last word nor the opportunity to definitively put to rest the story's central argument, since the goal is to keep viewers from disbelieving (Campbell 2016, p. 206; Koven 2007, p. 200).

Given that Discovery Network produces factual entertainment with pseudoscientific subjects across its many platforms, and this content is scheduled adjacent to programs which explicitly cross the line into the contrived (Campbell 2016, pp. 21, 185-86), it is of little surprise that the above formula has found its way into shark-themed shows that incorporate the Jaws script. Indeed, to draw in larger audiences, producers have opted to blend pseudoscientific topics like ghost hauntings with shark themes, as seen, for example, in Shark vs. GoPro (Rober 2021). This analysis will show that, despite the science hype, argumentation and entertainment techniques in Great White Serial Killer Lives closely track with the above criteria for pseudoscientific content, which exacerbate shark-human conflict, and disregard repeated calls to shift the negative reputation of the species for its impacts on public support for conservation. 


\section{Materials and Methods}

Great White Serial Killer Lives is the fourth in a five-installment series that features shark encounters off the waters of Surf Beach, California between 2008 and 2016. The fourth installment is the subject of analysis because it solves the mystery behind the encounters. Likely because of its climactic nature, Discovery marked the program's prominence by way of an enviable primetime slot at the outset of Shark Week 2017. Sister network Animal Planet also re-aired it on 11 January 2020, attesting to its long shelf life as a standalone program.

To distinguish the elements outlined in the above criteria, the author performed a transcription of the entire program and conducted a textual analysis of plot structure, narration, as well as verbal and audiovisual elements, to provide an in-depth look at how producers, writers, editors, and cast members put forward messages about the existence of a Jaws shark. No scientific instrument was used for analysis. The investigation of narrative forms like documentary is known for its "lack of a universal method of analysis", which requires operationalization of the methodology by way of the "cognitive purpose"-i.e., by defining the scope and aim of the research - within a distinct set of guidelines (Mikos 2014, p. 420; Mikos et al. 2008, pp. 82-95). Inquiry was also grounded in Critical Animal Media Studies (CAMS), which lies at the intersection of media and cultural studies, and utilizes both textual and content analysis to gauge how media representation of nonhuman animals such as sharks, who are tarnished by Jaws aspersions (Francis 2012; Le Busque et al. 2021a; Le Busque and Litchfield 2021; Aich 2021), affects their lived experience (Merskin 2015, p. 12).

Results provide an overview of plot structure divided by segments and sub-segments. Because viewing occurred without the advantage of ad insertion, story segmentation was assessed through breaks inserted in the editing process by producers and/or signaled via a change in location, characters, or subject matter. Shark visuals-coded as medium shots (MS), medium close-ups (MCU), close-ups (CU) and extreme close-ups (ECU)-were catalogued by assessing images of whole sharks and body parts like dorsal and eyes. Use of sound was described by tone and instrument wherever possible and gauged for how it may further a particular emotional response. Audiovisual elements were examined together since viewers encounter these cues jointly. They also contain pointers that guide audiences to feel in particular ways and take certain actions (Mikos 2014, p. 411), in this case, to fear sharks. Audiovisual elements, however, can also function to close down meaning and limit how the audience interprets information (D'Amico 2013, p. iv). Therefore, shark images in the program were also examined for purported "aggressive" poses; i.e., sharks with an open (and bloodied) mouth or nose, lunging at bait in- or off-frame, and vertically going up the water column reminiscent of the 1975 Spielberg movie.

Discussion was structured through the principal cast of characters, which followed the formula of a two-person investigative unit plus a skeptic. The first two are entertainment figures with established media relationships that help publicize their brand (Metz 2008, p. 343), while the third is a renowned white shark scientist. Since character objectives in storytelling are arranged through oppositions that maximize narrative tension (Dancyger and Rush 2007, pp. 63, 191), analysis focused first on the investigative team's arguments and how they built purported evidence for a Jaws shark. The input of the shark scientist, as he attempted to clarify pseudoscientific claims by means of established science, was examined last.

\section{Results}

\subsection{Plot Structure}

In Great White Serial Killer Lives, Brandon McMillan and Ralph Collier continue their search to unveil the mystery behind a series of strikes that recur every two years off the waters of Surf Beach, California. McMillan, introduced as a surfer, animal trainer, and TV personality, conducts witness interviews, while partner and "shark attack researcher" Collier is charged with collecting shark tooth fragments destined for a DNA database that 
will identify individuals behind the strikes in question. White shark biologist Michael Domaier, cast in the role of skeptic, must shed light on the argument that a supposed Jaws shark is haunting the area.

A bird's eye view of the plot reveals an introduction, seven segments, and twenty-two sub-segments. Except for the first segment, which features the most recent encounter, the remaining six segments briefly recapitulate the Surf Beach shark-human encounters between 2008 and 2014 in preceding installments. The case-stacking strategy mirrors the "shark frenzy", as it intersects with the crime and mystery format, to rehearse the idea of the white shark's criminality. The "whodunnit" scheme justifies the use of forensic science methodologies, such as evidence-collection and DNA analysis, to land the culprit. It also provides the main thrust of the drama (Campbell 2016, p. 57).

Since the introduction is designed to readily capture viewer attention, the male voiceof-god Narrator presents the events as a series of "brutal" incidents that have left the community reeling and wondering why they are occurring. He underscores that the twoperson investigative unit has put together a decade-long file of evidence and, by virtue of producers' time investment, attests to the thoroughness of the probe. Viewers are left to trust in the order of developments as the true account behind the incidents despite the fact that many plotlines can be fashioned from the same events and that the key to understanding a story's meaning is in tracking how it unfolds (Ellefson and Kingsepp 2004, p. 204).

The introduction also sets the tone for priming the sensationalist Jaws angle through 15 shots of white sharks chiefly in medium close-ups (MCUs) and 13 or 86.6 percent captured in purported aggressive displays: with open jaws or lunging. Visuals also include blood-in-the-water effects and beach warning signs accompanied by ominous sound motifs. This segment is meant to hook viewers by simulating the visceral experience of being on the receiving end of a white shark bite. It also short-circuits critical analysis since it is practically impossible to give into instinctual triggers and logically dissect the audiovisual imagery (Biancorosso 2010, p. 321).

Segment 1 chronicles a 1 September 2016 bite on a spear fisher in the waters off Devil's Jaw-Point Argüello-about 8 miles north of Surf Beach. The encounter is featured upfront because, fortuitously for the producers, the young man in question had mounted a GoPro camera on his spear gun and taped part of the proceedings. However, since the clips are not up to the visually dramatic standards of this kind of programming, reenactments of the shark closing in on the youth and grabbing his foot follow in short order. The visuals and narration, as in Jaws, are accompanied by sound effects of a frenzied drum that mimics the human heartbeat to evoke stress before a shark incident (Biancorosso 2010). Reenacted audio of an emergency call in a frantic woman's voice also amplifies the tension. The encounter is dubbed as "the latest", consonant with the story of a criminal Jaws-like shark at large.

The twenty-two sub-segments that follow launch new leads into the investigation. Apart from the introduction and segments 2-7, Collier is seen in 13 sub-segments and McMillan in 15. They appear together in two segments and three sub-segments to convey that they are on the same page. Domaier is featured in eight sub-segments-1, 2, 4, 5, 10, 11, 20 , and 22-while physically segregated from the other two on a boat off the area's coastal waters to denote his third-party role (Table 1 ). 
Table 1. Great White Serial Lives Plot Structure.

\begin{tabular}{lc}
\hline Segments and Sub-Segments & Cast Member(s) \\
\hline Introduction and 6 segments: Brief recap of shark encounters between 2008-2014; Collier & \\
and McMillan seen together in intro and segment 3. & McMillan, Collier (intro, seg 3) \\
Segment 1: Spear fisher off Devil's Jaw struck (2016); dubbed the most recent. & McMillan (seg 4, 5, 6, 7) \\
Segments 2, 4-7: McMillan (alone) interviews surfers, kayaker, and other witnesses in & \\
2008-2014 shark encounters. &
\end{tabular}

Sub-segment 1: Narrator makes the case that McMillan and Collier are thinking the shark culprit could be a female on a 2-year migration coming back to her hunting grounds. Domaier begs to differ. He is on site on a boat to deploy satellite tagging and find out whether the sharks are coming from the Farallon, Guadalupe, or Southern California.

McMillan, Collier Domaier

Sub-segment 2: Collier measures shark teeth involved in "attacks" and explains measurement technique. Domaier on boat shoots down methodology: inconsistency of tooth patterns. Notes that first 3 sharks measured between 16-17 ft., last one was $20 \mathrm{ft}$. He clarifies that it is simply more sharks traveling through the area.

Sub-segment 3: Report that kayaker was struck near Gaviota Beach (2015). Voice of male surfer interviewed by McMillan says that it felt like something massive hitting.

Sub-segment 4: Domaier hopes to capture sharks and tag them.

McMillan

Sub-segment 5: Domaier finds no sharks, only a whale carcass with shark bites.

Sub-segment 6: McMillan with Collier at Morro Bay (2015).

Narrator states they have solid evidence for a single shark in multiple attacks.

Collier, Domaier

Sub-segment 7: Narrator notes that Morro Bay is just 30 mi. north of Gaviota.

Collier bases his assertions that it could be the same shark based on 3 attacks in Morro Bay

by white sharks in the span of 11 days $30 \mathrm{~min}$. apart and separated by 400 yards.

Sub-segment 8: McMillan with male surfer who was hit (2015). McMillan states that shark was "stalking you" and surfer replies that it struck him as "predatorial."

Domaier

Domaier

Sub-segment 9: Collier with female surfer whose board was bit after the male surfer's board.

Collier measures distance of shark teeth on male surfer's and female surfer's boards and purportedly finds a match. Collier states that there is precedent for same shark coming back because the same shark attacked several people in 1916 and 2010.

Sub-segment 10: Narrator wonders if it is the same shark coming back on a two-year interval to kill. Domaier on boat interjects that there is no evidence of a shark that has figured out how to kill or eat people or that likes to do so but says nonetheless that the pattern of strikes coincides with his own discovery of the female 2-year migration cycle.

McMillan, Collier

Sub-segment 11: October 2016, 2 months after the spear fisher hit at Devil's Jaw. Domaier and assistants reel in and tag a $14 \frac{1}{2}$-ft. female shark. Long sequence.

Collier

Sub-segment 12: Guadalupe I-McMillan with "naturalist" / cage dive operator Jimi

Partington who explains how sharks eat elephant seals. McMillan asks a leading question, noting that if an 18-ft animal can take a chunk out of an animal that large (elephant seal), a human should be no problem. Narrator adds that a large female will leave the area pregnant.

Sub-segment 13: Collier expects to find out if same shark is "responsible" for the strikes.

Heads to morgue for shark tooth enamel from body of surfer killed in 2010 encounter, which is taken to Cal Lutheran for DNA analysis, which is described as a revolutionary methodology.

Sub-segment 14: Collier goes digging for more clues: fragments left behind in any of the attacks to find the shark "responsible."

McMillan

Sub-segment 15: Guadalupe II: McMillan with naturalist/cage diving operator Jimi Partington who touches nose of baited shark so mouth gapes. Dubbed as rarely-seen behavior. Long sequence.

Collier

Domaier

Domaier

McMillan

Collier

Collier

McMillan 
Table 1. Cont.

\begin{tabular}{l} 
Segments and Sub-Segments \\
Sub-segment 16: Collier with sea otter biologist in Morro Bay to collect more shark tooth \\
fragments. Tally of 160 otters shark-bitten. \\
\hline Sub-segment 17: Collier collects more tooth fragments in Santa Ynez, California from a \\
shark-bit kayak in 2014. Owner notes that shark rolled kayak over and came out of the water \\
Dorsal size: 3 feet. Domaier on boat has also collected a tiny bit of skin sample from dorsal of \\
female tagged for DNA analysis.
\end{tabular}

Sub-segment 18: Collier looks to have the DNA analysis done at Cal Lutheran and find out whether there is a match for the shark behind the 2010 surfer death.

Sub-segment 19: Guadalupe III-McMillan with Jimi Partington. Clip of Shark Emma going after backup air supply of Jimi's submersed cage.

Sub-segment 20: Domaier has tagged a $14 \frac{1}{2}$-ft female, a $17-\mathrm{ft}$. female, and a $10-\mathrm{ft}$. male. Reports location on satellite tracking device. Only first female located.

Sub-segment 21: Collier and McMillan wait for results from Cal Lutheran: no match found. Narrator says with tooth enamel samples, investigation now building a genetic database of white sharks in the region. Collier: identify shark "responsible."

Sub-segment 22: No match found. Narrator notes that number of hits off Surf Beach can be explained by more people recreating in the water coming across an increasing number of white sharks. Domaier encounters a small elephant cove that puts an end to the mystery behind the strikes because it functions as a shark 'refueling stop'. Narrator notes that

Domaier, McMillan humans are not on the shark menu since sharks are following a growing number of seals.

But as McMillan takes to the water on his surfboard, Narrator muses about the thought of a giant hungry female coming back to the area and another appointment with the shark.

Cast Member(s)

Collier

Collier

Collier

Total Appearances: McMillan: 15; Collier 13 (together in 5); Domaier: 8 (on boat)

\subsection{Visuals}

The program includes a total tally of 205 images of sharks of various sizes (ECU-MCUMS), with 89 or 43.4 percent in presumably "aggressive" poses-with mouth open and lunging at bait and, like Jaws, traveling vertically up the water column in sub-segments 1,15 , and 17 (Table 2). This representation effectively places sharks in reenactments that make the case against themselves, and strenghtens the argument that nonhuman animals deserve legal rights that protect them from humans (Dunayer 2015, p. 92).

While sharks who are marked for consumption are cut up for parts and sold as nonliving objects or "absent referent[s]" (Adams 2015, p. 60), when inscribed as predators of humans, their body parts take on additional meaning that registers "the term shark ... as a signal of horror" (Lerberg 2016, p. 38). These projections redefine sharks by way of an exclusively reductive approach that objectifies them by way of "the fin, bite and death ... [as] the dominant sign of their character" (Lerberg 2016, p. 35).

The dorsal in the program functions as a trope for the shark's "stalking" in line with the Jaws formula (Neff 2015). It appears in 12 shots-in segments 3 and 4 and in subsegment 2, 3, 6, 9, 12, and 17-in an assortment of medium shots (MS), medium close-ups (MCU), close-ups (CU), and extreme close-ups (ECU) to denote the animal's threatening yet slippery presence. Only in sub-segments 11 and 20 are the sharks acted upon when their dorsals are tagged.

The shark's consciousness, as in Jaws, is suggested through a handful of reenactments of dangling legs on a surfboard or individuals on a kayak from the perspective below. It is also centered on the eye-usually photographed one at a time as it trains on the cameraand deployed through progressively larger extreme close-ups (ECUs) across segment 4 and sub-segments $1,3,4,8,9$, and 12 to convey the idea of looming danger as the shark draws near. These images assume that sharks in proximity to humans per force represent a threat because they not only injure but return time and again to kill (Neff 2015, pp. 114, 123). 
Table 2. Shark Visuals.

Total images of sharks of various sizes and ages: 205.

Eighty-nine visuals or 43.4 percent in presumably aggressive poses: whole sharks with mouth open, lunging, and in Jaws poses.

Shark body parts: dorsal ("stalking"), eye ("consciousness")

\section{Segment/Sub-segment Sharks Totals and in Aggressive Poses \\ Dorsal and Eye Number, Shot Size, and Effects (FX)}

\begin{tabular}{|c|c|c|c|c|}
\hline Segment/Sub-Segment & Total & Aggressive & Dorsal & Eye \\
\hline Introduction: & 15 & 13 & & \\
\hline Segment 1: & 7 & 2 & & \\
\hline Segment 2: & 4 & 3 & & \\
\hline Segment 3: & 0 & 0 & $1 \mathrm{MCU}$ & \\
\hline Segment 4: & 5 & 1 & $1 \mathrm{MCU}$ & 2 ECU shark with eye on camera \\
\hline Segment 5: & 2 & 2 & & \\
\hline Segment 6: & 4 & 2 & & \\
\hline Segment 7: & 7 & 4 & & \\
\hline Sub-segment 1: & 9 & 4 Jaws & & 1 ECU right eye and FX \\
\hline Sub-segment 2: & 1 & 1 & $1 \mathrm{CU}-\mathrm{ECU}$ & \\
\hline Sub-segment 3: & 4 & 2 & $\begin{array}{l}1 \mathrm{CU} \\
1 \mathrm{MS}\end{array}$ & $\begin{array}{l}1 \text { blurry CU eye SLO MO } \\
1 \text { ECU eye }\end{array}$ \\
\hline Sub-segment 4: & 3 & 0 & & 1 very large ECU eye \\
\hline Sub-segment 5: & 0 & 0 & & \\
\hline Sub-segment 6: & 6 & 2 & $\begin{array}{l}1 \mathrm{MCU}-\mathrm{CU} \\
1 \mathrm{MCU} F X\end{array}$ & \\
\hline Sub-segment 7: & 3 & 2 & & \\
\hline Sub-segment 8: & 4 & 3 & & 1 larger ECU eye \\
\hline Sub-segment 9: & 6 & 3 & $\begin{array}{l}1 \mathrm{ECU} \\
1 \mathrm{CU}\end{array}$ & 1 huge ECU eye \\
\hline Sub-segment 10: & 3 & 1 & & \\
\hline Sub-segment 11: (shark reeled in, dorsal tagged) & 29 & 0 & $\begin{array}{l}3 \mathrm{MS} \\
2 \mathrm{MCU}\end{array}$ & \\
\hline Sub-segment 12 & 10 & 4 & $\begin{array}{l}1 \mathrm{ECU} \\
1 \mathrm{MS}\end{array}$ & CU-ECU shark with eye on camera \\
\hline Sub-segment 13 & 8 & 7 & & \\
\hline Sub-segment 14 & 6 & 5 & & \\
\hline Sub-segment 15 & 35 & 20 Jaws & & \\
\hline Sub-segment 16 & 2 & 2 & & \\
\hline Sub-segment 17 & 6 & 1 Jaws & $1 \mathrm{MCU}$ & \\
\hline Sub-segment 18 & 0 & 0 & & \\
\hline Sub-segment 19 & 6 & 2 & & \\
\hline $\begin{array}{l}\text { Sub-segment } 20 \\
\text { (tag attached to dorsal) }\end{array}$ & 7 & 0 & $\begin{array}{l}2 \mathrm{MCU} \\
1 \mathrm{CU}\end{array}$ & \\
\hline Sub-segment 21 & 2 & 1 & & \\
\hline Sub-segment 22 & 11 & 2 & & \\
\hline
\end{tabular}

While a projection of the primate eye's preeminence, these shark eye images also reproduce the human-nonhuman animal encounter by ascribing the animal a "power" that leaves the 
human looking over in fear. In so doing, they avoid pointing out its correlate: that "the eyes of an animal, when they consider a [hu]man are attentive and wary" (Berger 2009, pp. 4-5). The shark's positioning in the frame - typically at center with mouth open to denote aggressiondisavows the reality that the camera is the aggressor, as the individual photographed observably reacts with caution or fear, while the Narrator doubles down on the species' hostile nature.

\subsection{Sound}

Shark visuals occur alongside nefarious sound effects with dissonant tones that include the pounding of a drum, which emulates a human heartbeat under stress to create suspense (Biancorosso 2010; Winters 2008). The use of percussion plates marks the shark's ominous presence as if materializing out of nowhere like a menace. Sound effects also emulate submarine sonar and the sound of the wind in desolate landscapes to denote the shark's rogue and spectral attributes as $\mathrm{s} /$ he silently stalks victims and disappears like a ghost into the dark ocean in line with eco-horror aesthetics. Electronic organ-like effects associated with the shark's savagery and crunching aural effects that mimic the shark biting are part of the sensory barrage designed to overwhelm the viewer. These foreboding, discordant tones do not let up until the waning moments and corroborate that the aim of the program is to communicate a persistent sense of danger in line with the species' purported villainous nature. Consonant with spectacle, these sound effects are also designed to distract viewers from pondering the implausible premise of a Jaws shark on the loose.

\section{Discussion}

\subsection{The Investigative Team and the Jaws Shark: The White Shark as Monster}

As seen in Campbell's model, the investigative team's role, which is aligned with both network's and producers' interests, is that of relentlessly pushing the existence of the Jaws shark as monster. Monster imagery conforms to eco-horror conventions that express the "aesthetics of transgression", which destabilizes the fanciful notion of human control over nature (Fuchs 2018a, pp. 1, 13; DeMello 2021, p. 400). These conventions do not favor identification with the shark (Fuchs 2018b, p. 12), but instead prioritize the triumph of righteous humans, who are assumed to have an ontological decency that the monster lacks by virtue of having proven his or her status through lethal incidents (Carroll 1990, pp. 16, 141).

In segment 2, the Narrator first posits the existence of such a shark by venturing that the strikes are not a "one-time random thing" but a pattern that recurs every two years, while, in sub-segment 1, he expands on the idea by noting that McMillan and Collier believe that the culprit may be a single individual-a female-coming back to her hunting grounds every other year. The "shark frenzy" exercise, seen in the introduction and segments 1-7 by stacking events dubbed as "attacks", resumes in sub-segment 3 with a report of a shark biting a fisherman's kayak off Gaviota Beach in 2015.. Sub-segment 6 deploys news clips which feature said individual relaying that the shark emerged with the front of the kayak in his mouth and gesturing that the eye was yea big. His testimony prepares viewers for two visually compelling cases off Morro Bay in 2015.

To introduce these sections, in sub-segment 7 the Narrator steps up the tension by observing that Morro Bay is only 30 miles north of Gaviota Beach. Collier, joined by McMillan at the scene, argues that three "attacks" occurred in 11 days removed by a mere $30 \mathrm{~min}$ and 400 yards, purportedly enough evidence to suspect one shark. While fear-laden and suspenseful, these assertions disregard that bites only appear to be a pattern, and instead are "independent, random and rare" and anything but "intent-based" (Pepin-Neff 2014). The Narrator nonetheless maintains that the investigators have found proof of a bite match that will buttress their claims.

As McMillan visits with a male surfer whose board was bitten in Morro Bay, he observes in sub-segment 8 that while most sharks take a bite and leave, in his case, the shark returned as if "stalking you", and by way of this leading statement, extracts from the surfer the observation that the shark's behavior felt "predatory." The inserted visual-a 
slow motion extreme close-up (ECU) of a white shark swimming from left to right of the frame- underscores the large eye to drive home the idea of a stalking animal in the Jaws script (Neff 2015). The sound effects have a sinister quality achieved by scaling-up dissonant notes reminiscent of monster imagery in eco-horror movies.

In sub-segment 9, Collier's visit with the female surfer, whose surfboard was likewise damaged in another Morro Bay encounter, yields recollections of "an enormous shape" underneath, which subsequently emerged and destroyed her board. Two extreme close-ups (ECUs) — of a shark whose jaws open and close in slow motion and of a shark eye as the animal slowly submerges-are appended to her statements. Slow motion and doubling effects extend the display of the purported killer to reiterate the idea of a predator stalking his or her human victim. The view of the eye, accompanied by submarine sonar sound effects, denotes a specter that slips in and out of the scene unnoticed consonant with the white shark's criminal image. Collier tells the female surfer about her counterpart's encounter a short distance away and only half an hour earlier, and posits that the same shark could be behind both events. The Narrator interjects that there is historical precedence for white sharks assailing multiple people, or up to two during the same day. As Collier proceeds to measure her board, he finds a bite match that presumably lends his theory credibility, which the Narrator bolsters by reiterating the one shark-multiple-aggressions theory. This supposed match, as it relates to earlier stalking allegations, fails to hold up against the repeatability standards of independent scientific assessment. For good reason, Domaier challenges the methodology in sub-segment 2 for its lack of precision. Nonetheless, the Narrator again ponders whether the same shark could be returning every two years to strike.

The lab scene in sub-segment 13 features Collier preparing shark tooth fragments for DNA analysis collected from kayaks, surfboards, and dead sea otters as a way to find the shark "responsible." He couches his inquest in moral terms even though gauging nonhuman animal behavior by way of human standards is both unethical and absurd (Pollo et al. 2009, p. 1358). This section includes visuals of sharks with jaws showing, lunging at bait, and coming straight at the camera. Shots incorporate three slow-motion sequences (MCU, MS), which work to extend the display and amplify the shark's supposed monster-like traits.

While DNA analysis from shark enamel is described as a revolutionary technology designed to impart scientific credibility to the investigation, it speaks to an entirely different set of narrative prerogatives that Linda Williams has termed the melodramatic mode. The melodramatic mode, which pervades American film, television, theater, and literature, filters events through simplistic Manichean clashes that pit good against evil to underscore the tribulations of innocent humans and help establish their moral credibility in the story. It summarily does away with complexities because its role is to ensure that moral authority is located squarely with the human victims (Williams 1998, pp. 72, 74, 77, 80, 82). Since white sharks are pelagic, hard-to-track, and unable to survive long in captivity, they have dodged the physical and psychological impacts of enclosure imposed on other species and, for this reason, are reviled for daring to remain elusive and beyond human control (Peace 2015). The DNA-matching is therefore a way of encircling and entrapping the white shark in line with the Jaws formula as proxy for exacting a quintessentially melodramatic form of justice for the human deaths in the story. This imagery projects human control and authority over shark species and appraises them not only as subordinate but ultimately as without any "ontological basis of existence" apart from human evaluation (Ford and Hammerton 2020, p. 150).

The shark's monster image reaches a crescendo in sub-segments 12, 15, and 19 when McMillan visits with Jimi Partington, who heads a cage diving tourist operation in the waters off Mexico's Guadalupe Island. Guadalupe is well known for large female white sharks who travel to the area to feed on elephant seals and to mate. Sub-segment 12 features Partington explaining how sharks eat-with teeth that resemble "steak-like knives" and by swallowing prey whole. He details migration patterns that McMillan and the narrator 
attempt to tie to the Surf Beach events to buttress the idea of a returning Jaws shark. This sub-segment features three extended slow-motion sequences of sharks-11 s (MCU-CU, MS-MCU), $6 \mathrm{~s}(\mathrm{CU})$, and $15 \mathrm{~s}(\mathrm{CU}-\mathrm{ECU})$ - that enlarge the shark image and stress the dangers at stake.

Sub-segment 15, the longest section in the entire program, features a sequence in which Partington recurrently baits a large white shark. As the lured individual comes out of the water following the pulley with bait, Partington touches the nose area so that the jaw gapes. This section incorporates no less than a total of 35 shots, and 20 in which the shark comes out of the water with mouth open lunging at the bait. At one point, the shark miscalculates and lands the bite on a metal railing in front of Partington in a sequence repeated no less than 10 times in slow motion to underscore how close he came to danger. (This sequence also appears in the introduction as a "tease" to draw in the viewer as well as in sub-segment 14). To distract from any harm to the baited individual, the Narrator describes Partington as a shark champion who aims to school the public at large about the species' "true nature" and whose prime concern is their welfare. The entire display is justified as a way of showing the aftereffects of shark encounters. Despite avowing that the shark is not being aggressive but only reacting reflexively, the narrator's comments reify the encounter as eminently destructive by making clear that anything in the way of the jaws is imperiled. To reiterate the idea of the shark as menace, this sub-segment also includes a visual of a white shark going up the water column reminiscent of Jaws. Sub-segment 19, for its part, features a clip of Emma, a supposed hostile shark who is seen striking the back-up air supply of Partington's submerged cage. The segment ends with the Narrator's caution to never face away from a white shark.

Despite the purported educational angle, the Guadalupe segments are about the spectacle of the adult white shark's dominant position in the marine food chain and viewers imagining the horror of getting caught in the bloody experience through the appropriate distance of televisual images. This display obscures larger issues like shark species' role in performing ecosystem functions and services, which, in turn, correlates marine nonhuman animals' body (and jaws) size, mass, and mobility with nutrient storage, transport, cycling, and dispersal in promoting biodiversity and genetic variance (Tavares et al. 2019). As spectacle is known to do, this section has the potential to lull viewers into passivity about solving marine environmental problems by encouraging audiences to merely sit back and enjoy the show. For good reason, these kinds of representations are considered ecoporn since they disconnect images from referents in the real world and re-contextualize them through objectification (D'Amico 2013, pp. 149, 150, 206). The rhetorical function of this imagery is to control discourse parameters in order to reify the shark's savagery. In the process, it confuses the real and the representational with no ultimate return to the real (Merskin 2018, p. 47).

\subsection{The Shark Scientist}

As the "skeptic" in the story, white shark biologist Michael Domaier is given the task of conveying shark science accurately and dispelling any pseudoscientific theories about the existence of a Jaws shark. The camera introduces him to viewers by photographing him from a lower angle upward to signal his status as an authority. Domaier disagrees with most of the theories floated about a "killer" shark on the loose but hopes to uncover whether the sharks hail from the waters off the Farallon, Guadalupe Island, or from Southern California proper, and whether a new adult hotspot has surfaced. He makes clear that the area is already known as a pupping ground where sharks can safely grow, explore their surroundings, and investigate new habitats. He also notes that the "killer" shark theory is unsound and that the increase in encounters is due to a larger number of individuals traveling through the area. He supplies the viewer with a crucial sense of process that differentiates shark growth stages, behaviors, and migration patterns lacking in Jaws-type descriptions. For example, he explains that "[w]hen ... sharks grow up they've got to figure out where they want to be as ... adult[s]." This information implies trial and error 
and a learning curve, and counteracts the decontextualized images of sharks of various ages and sizes baited to pass for a villainous movie character.

When, in sub-segment 10, the Narrator again questions whether the same individual is behind the previous incidents with kayakers and surfers, Domaier categorically shoots down the notion of a reprobate shark and notes that no evidence exists for "a shark that's figured out how to kill people ... likes to kill ... and ... eat people." His statements, however, are undercut by appended images of a white shark (ECU) with mouth opening in slow motion accompanied by effects that mimic the sound of the wind through inhospitable, desolate landscapes, as well as an 8-s (MS-MCU-CU) sequence of a white shark coming at the camera to the pounding of a drum and high dissonant notes. When Domaier points to the compelling nature of the two-year strike interval at Surf Beach, given that his own research had uncovered the female migration cycle, images of the surfers killed in 2010 and 2012 alongside blood-in-the-water effects are attached to his statements. The inserted visuals and sound effects transform the degree of theorization that is part and parcel of the scientific method into outright interference with shark science to keep alive the idea of a Jaws shark in the viewer's mind.

The extensive reeling and tagging sequences of a $14 \frac{1}{2}$-ft. female in sub-segment $11-$ which only rivals in duration the Guadalupe "monster" display in sub-segment 15-on the other hand, resembles a dangerous cowboy roping adventure that re-images the ocean and the shark within it as a frontier-like environment that necessitates conquering. This lengthy exercise, perilous for both humans and nonhumans alike, is prioritized over other forms of shark science because it provides tantalizing entertainment for Discovery's viewer demographic. It also calls attention to the lack of female shark scientists in the program given that women make up half of the American Elasmobranch Society (Shiffman 2018).

In sub-segment 20, audiences get a glimpse of shark satellite-tracking technology in action. While arguably also a way of encircling the white shark, this technology investigates shark population sizes and distributions in the service of recovery and offers the program a measure of scientific credibility. However, of the three tagged individuals, including a $17-\mathrm{ft}$. female and a $10-\mathrm{ft}$ male, the technology can only pinpoint the $14 \frac{1}{2} \mathrm{ft}$. female's location even as the expectation is that all will return to the area. Nonetheless, given the program's "slippery" shark imagery, the technology's limitations also reaffirm the white shark's elusive aura.

When the DNA results arrive in sub-segment 21, predictably, no match is found. In sub-segment 22, the Narrator finally concedes that the events of the past five years may be due to more humans in the water encountering an increasing number of sharks. Domaier doubles down on Jaws shark speculation and reaffirms: "[W]hat's happened at Surf Beach is not ... one shark." He also comes across a small cove with a new elephant seal colony, which he describes as an important shark interim feeding station in 85 miles. The discovery shows that the elephant seal population, almost driven to extinction by human hunters, is recovering and that the sharks are simply following after them. Since the investigation set out to uncover the motive for the strikes, the Narrator acknowledges it as solving the Surf Beach mystery for its location some miles south. It is also only after this revelation that he notes that humans are not shark prey, even as those who insist on swimming near seal colonies expose themselves to considerable risk.

Despite this admission, the Narrator expresses trepidation about the thought of a giant, hungry female making her way back to the Surf Beach area. As McMillan takes to the waves on his surfboard, the image of a white shark (CU) under the water line fills the frame in slow motion accompanied by a low dissonant wind-like effect, crescendo sizzling, and a pound on percussion plates. An inscription in the frame teases about the next appointment with the shark on 20 October 2018 at 6:02. All the science-hyping notwithstanding, Domaier is ultimately not allowed to cast aside the idea of a Jaws shark since producers do not intend to discard the image for the considerable profit it represents.

The voice-of-god Narrator, whose role in the documentary format is to remain above the fray, functions as the driving force behind the idea of the Jaws shark in the program. 
Of the 52 references to the term "attack", which appear consistently in the shark research literature to inscribe sharks as predators of humans and to commoditize fear (Le Busque et al. 2019, p. 2; McCagh et al. 2015, p. 274; Neff 2015; Muter et al. 2013, p. 190, 34 are made by the narrator. This voice also provides for turning points that insistently push forward the Jaws scheme through the idea of a single shark's intentional strikes in a two-year repeating pattern (segment 7 and sub-segments 1, 6, 10, and 15). Argumentand evidence-presentation techniques exploit knowledge gaps in shark science-such as difficulty in assessing both white shark population numbers due to small- and large-scale migrations and distribution-related environmental drivers across regions (Huveneers et al. 2018, pp. 1, 5) - to confuse viewers with the idea of a returning Jaws shark.

It goes without saying that Jaws imagery is counterproductive to the text's scientific angle not only because it rehashes clichés that weaken science in the public eye as an evaluative, measured system of inquiry, but because it fundamentally devalorizes shark individuals and species in their totality (Kueffer and Larson 2014, p. 721). Although documentary is expected to blend science with entertainment (Evans 2015, p. 266), the balance in the program is struck in favor of eco-horror features that are consonant with criticism of factual entertainment's shift away from production of thoughtful scientific content toward pseudoscientific programming that slides head first into fiction (Campbell 2016, pp. 1, 2).

Leading questions designed to extract emotionally-charged answers and unquestioned witness testimony about sharks explicitly targeting humans, as well as wide use of science accouterments, like staged lab scenes and the participation of scientists who provide specimens for DNA analysis, attempt to add scientific credibility to the proceedings. "Factfinding" trips up and down the Central and Southern California coast to collect shark tooth samples, as well as excursions to Guadalupe Island to display the power of a shark bite and tie visiting sharks to Surf Beach incidents also predictably yield a lack of conclusive evidence that one shark is behind the encounters. Aside from furthering the narrative's forward thrust in the manner of a TV crime investigation, said jaunts amount to little more than mere diversions.

The shark scientist in the role of skeptic does furnish much needed clarification as he solves the "motive" for the Surf Beach incidents. Yet, tantalizing images of sharks with purportedly bad intentions are also spliced in to undercut his assertions. This imagery suggests that the shark scientist, although recognized as an authority, is not allowed to definitively put to rest the idea of a Jaws shark regrettably inspired by a movie featuring a 25-ft. mechanical shark. Even though Domaier is introduced as an expert in white shark science, he is also described as an additional investigator, which understates his authority. This move is detrimental to shark conservation since scientists are trusted by the public to be credible purveyors of information and are also influential in engendering attitude change by increasing the level of concern about a public problem (Oxley et al. 2014, pp. 256, 258, 264; Petty and Wegener 1998; Pew Research Center for the People and the Press 2009). By undercutting Domaier's authority and input in the service of entertainment, producers missed out on the shark scientist's ability to create the kind of impactful change that fictional films with their "suspension of disbelief" directive cannot offer. Objectivity techniques of science in TV documentary also enabled producers to "balance" the investigative unit's Jaws shark speculations against scientific assertions as if these were equally weighted, despite that the team's expertise was not readily discernible as is typical of pseudoscientific programs (Campbell 2016, pp. 186, 192; Metz 2008, p. 343). Consonant with pseudoscience, then, the program's chief aim was to prevent viewers from disbelieving in the mythical Jaws character by exploiting their lack of familiarity with sharks and enabling continued profiteering from defamatory representations.

Characteristic of the reversals that occur in Hollywood entertainment, two years before the fourth installment's first airing, Kurr and McMillan disavowed the idea of a Jaws shark by respectively stating in the same interview: "[E]verybody knows ... [that] a great white shark is just trying to eat. .. They're not trying to target humans ... " and "the more you work around a shark, the more you realize ... Jaws definitely got it wrong; they're not 
bloodthirsty killers ... [nor] mindless .... [but] one of the more intelligent animals in the world ... " (Bierly 2015). The strategy of clearing up misconceptions outside the program's boundaries confirms that producers wish to distance themselves from the misinformation they sow while reaping the financial benefits offered by sponsors. Yet, treating cinematic or televisual projections of shark images as if they occurred independently of ethical concerns is a non-starter (Ford and Hammerton 2020, p. 161). Further, decisions to stage white shark recovery as a threat to humans are ill-considered given that the release of the Spielberg's Jaws intersected with the emergence of the environmental movement and, as such, is seen as backlash against these concerns (Ingram 2000, p. 88). Rehashing this kind of imagery during an ongoing extinction event that scientists, researchers, NGOs, and even environmental organization donors are feverishly attempting to check and reverse decidedly registers as both profoundly anti-science and anti-conservation.

\section{Conclusions}

The proliferation of pseudoscience in factual programming and producers' decision to dedicate resources to complete fictions that amplify the entertainment factor and skimp on science is especially deleterious in the case of sharks whose image widely diverges from anthropocentric norms and the phylogenetically closer species for whom most humans feel empathy (Gibbs 2020, p. 11; Bornatowski et al. 2019, p. 34; Ingham et al. 2015). Hostile shark representations are not trivial since they aggravate perceived human-wildlife conflict, instill fear that foils funding appeals during conservation campaigns, and harm these nonhuman animals through species vilification that has real-life consequences for them.

Human-wildlife conflict is known to increase with the perpetuation of pseudoscientific attributes and culturally dependent anthropomorphisms that must be offset with factual knowledge and careful image-shaping of the species in question (Jürgens and Hacket 2021, pp. 12, 14; Apps et al. 2018, p. 1). Lowering fear of sharks by providing scientific information and focusing on the minimal risk of strikes (Pepin-Neff and Wynter 2018a; Aich 2021, p. 1), as well as emphasizing bite unintentionality and species' vulnerability have been found to engender a more favorable opinion of these nonhuman animals (Lucrezi et al. 2019, pp. 9, 10).

Remedying routine omission of white sharks' protected status across media genres also remains pivotal given that it veils systemic human predation of these species and the need for effective transnational legal protections. For this reason, advocating for the human right to all environments regardless of impacts should also be avoided since sharks have rights to their habitats and conservation requires a multi-decadal approach (Ford and Hammerton 2020, p. 151; Frisch and Rizzari 2019). In addition, given that adverse encounters are a result of miscalculation, the term "attack" should be discarded because it places the entire responsibility on the shark. Media practitioners should ideally follow new prescribed uses that label these interactions as adverse (Yuhas 2021), and/or deploy terms that accurately convey shark error.

Research shows that the greater a species' decline, the more intense public pressure becomes to ensure improvement in shark management and conservation (Boissonneault et al. 2005, p. 1). Social scientists have also observed trends toward greater biophilia that are driving more effective conservation policy (Manfredo et al. 2020). Enlarging species coverage and scientific content to address shark roles in marine ecosystem health as well as supplying critical-anthropomorphic portraits that personalize these nonhuman animals (Whitley et al. 2021, p. 840; Qirko 2017) can contribute to their conservation by enhancing human empathy. In like manner, reporting on new scientific discoveries, such as white shark preferences, which coincide with associations that suggest the existence of friendships (Schilds et al. 2019; Solstice Media 2019), can work to underscore individuality in a positive light and tap biophilic trends. Only by shifting imagery away from traits, behaviors, dispositions, and values that solely suit ill-fitting human standards, and acknowledging sharks' intelligence, emotions, and preferences, progress can be made toward respectfully addressing these nonhuman animals as planetary stakeholders. 
Funding: This research received no external funding.

Institutional Review Board Statement: Not applicable.

Informed Consent Statement: Not applicable.

Conflicts of Interest: The author declare no conflict of interest.

Disclaimer: Wildlife** refers to nonhuman animals who are either free-living or non-domesticated. No derogatory meaning is intended.

\section{References}

Adams, Carol. 2015. Consumer Vision: Specieism, Mysoginy, and Media. In Critical Animal and Media Studies. Edited by Núria Almiron, Matthew Cole and Carrie P. Freeman. Routledge Research in Cultural and Media Studies. London and New York: Taylor and Francis, pp. 56-73.

Aich, Raj Sekhar. 2021. Jaws and Beauty: Reflections on Great White Shark demystification. Academia Letters 2869: 1-6. [CrossRef]

Aitzen, Samantha. 2017. 'Great White Shark Serial Killer Lives' Is a True Story \& This Shark Week Special Is Looking for Answers. Bustle.com. July 23. Available online: https:/ / www.bustle.com/p/great-white-shark-serial-killer-lives-is-a-true-story-this-sharkweek-special-is-looking-for-answers-71764 (accessed on 6 January 2020).

Apps, Kirin, Kay Dimmock, and Charlie Huveneers. 2018. Turning wildlife experiences into conservation action: Can white shark cage-dive tourism influence conservation behaviour? Marine Policy 88: 108-15. [CrossRef]

Barcia, Laura Garcia, Juana Argiro, Elizabeth A. Babcock, Cai Yong, Stanley K. H. Shea, and Demian D. Chapman. 2020. Mercury and arsenic in processed fins from nine of the most traded shark species in the Hong Kong and China dried seafood markets: The potential health risks of shark fin soup. Marine Pollution Bulletin 157: 111281. [CrossRef] [PubMed]

Berger, John. 2009. Why Look at Animals. Westminster: Penguin.

Biancorosso, Giorgio. 2010. The Shark in the Music. Music Analysis 29: 306-33. [CrossRef]

Bierly, Mandy. 2015. 'Shark Week': Inside 'Return of the Great White Serial Killer'. Yahoo Entertainment. July 6. Available online: https://www.yahoo.com/entertainment/shark-week-return-great-white-serial-killer-alien-123344983005.html (accessed on 10 August 2020).

Boissonneault, Marie-France, William Gladstone, Paul Scott, and Nancy Cushing. 2005. Grey Nurse Shark Human Interactions and Portrayals: A Study of Newspaper Portrayals of the Grey Nurse Shark from 1969-2003. Electronic Green Journal 1. [CrossRef]

Bornatowski, Hugo, Nigel E. Hussey, Cláudio L. S. Sampaio, and Rodrigo R. P. Barreto. 2019. Geographic bias in the media reporting of aquatic versus terrestrial human predator conflicts and its conservation implications. Perspectives in Ecology and Conservation 17: 32-35. [CrossRef]

Brewer, Paul R. 2012. The trappings of science: Media messages, scientific authority, and beliefs about paranormal investigators. Science Communication 35: 311-33. [CrossRef]

Brown, Elizabeth. 2016. How a Century of Fear Turned Deadly for Sharks. Florida Museum. June 26. Available online: https: / / www.floridamuseum.ufl.edu/science/how-a-century-of-fear-turned-deadly-for-sharks (accessed on 17 July 2020).

Campbell, Vincent. 2016. Science, Entertainment and Television Documentary. London: Palgrave MacMillan.

Cardeñosa, Diego, Andrew T. Fields, Elizabeth A. Babcock, Huarong Zhang, Kevin Feldheim, Stanley K. H. Shea, Gunter A. Fischer, and Demian D. Chapman. 2018. CITES-listed sharks remain among the top species in the contemporary fin trade. Conservation Letters 11: 1-7. [CrossRef]

Carroll, Noël. 1990. The Philosophy of Horror: Or, Paradoxes of the Heart. London and New York: Routledge.

Cavanaugh, Patrick. 2020. Shark Week: Air Jaws Director Jeff Kurr Looks Back at the Legacy of the Discovery Channel Series. Comicbook.com. August 7. Available online: https://comicbook.com/tv-shows/news/shark-week-air-jaws-jeff-kurr-directorinterview-discovery-channel/ (accessed on 19 August 2020).

Ceballos, Gerardo, Paul R. Ehrlich, Anthony D. Barnosky, Andrés García, Robert M. Pringle, and Todd M. Palmer. 2015. Accelerated modern human-induced species losses: Entering the sixth mass extinction. Science Advances 1: e1400253. [CrossRef] [PubMed]

D'Amico, Lisa Nicole. 2013. Ecopornography and the Commodification of Extinction: The Rhetoric of Natural History Filmmaking, 1895-Present. Ph.D. dissertation, Texas A\&M University, College Station, TX, USA.

Dancyger, Ken, and Jeff Rush. 2007. Alternative Scriptwriting: Beyond the Hollywood Formula, 4th ed. Waltham: Focal Press.

DeMello, Margo. 2021. Animals and Society: An Introduction to Human-Animal Studies, 2nd ed. New York: Columbia University Press.

Donovan, John, and Dan Morris. 2013. Sharks: Why We're Obsessed with This Perfect Movie Villain, and Why That's Bad. ABC News. August 8. Available online: https://abcnews.go.com/Entertainment/sharks-obsessed-perfect-movie-villain-bad/story?id=1988 6673 (accessed on 25 August 2020).

Duhaime-Ross, Arielle. 2014. How Shark Week Screws Scientists. Discovery Is Alienating the Very People Who Supply Its Content: Scientists. The Verge. August 13. First published 2013. Available online: https://www.theverge.com/2014/8/13/5998745/howshark-week-screws-scientists (accessed on 14 July 2020).

Dulvy, Nicholas, Colin A. Simpfendorfer, Lindsay N. K. Davidson, Sonja V. Fordham, Arnie Bräutingam, Glenn Sant, and David J. Welch. 2017. Challenges and Priorities in Shark and Ray Conservation. Current Biology 27: R565-R572. [CrossRef] 
Dunayer, Joan. 2015. Mixed Messages: Opinion Pieces by Representatives of US Nonhuman-Advocacy Organizations. In Critical Animal and Media Studies. Edited by Núria Almiron, Matthew Cole and Carrie P. Freeman. Routledge Research in Cultural and Media Studies. London and New York: Taylor and Francis, pp. 91-106.

Dunkel, Tom. 2015. Will Discovery Channel's Shark Week Continue to Swim in Strange Waters? The Washington Post. June 18. Available online: https:/ / www.washingtonpost.com/lifestyle/magazine/great-white-hope/2015/06/15/d6b2c7be-056d-11e5-a428-c9 84eb077d4e_story.html (accessed on 17 August 2020).

Edgerton, Gary R. 2001. Television as Historian: A Different Kind of History Altogether. In Television Histories: Shaping Collective Memory in the Media Age. Edited by Gary R. Edgerton and Peter C. Rollins. Lexington: University of Kentucky Press, pp. 1-16.

Ellefson, Merja, and Eva Kingsepp. 2004. The Good, the Bad and the Ugly: Stereotyping Russia the Western Way. In News of the Other: Tracing Identity in Scandinavian Constructions of the Eastern Baltic Sea Region. Edited by Kristina Riegert. Nashwauk: Northern Perspectives, vol. 6, pp. 203-22.

Environmental News Network. 2020. Plastics Found in Sea-Bed Sharks. July 22. Available online: https://www.enn.com/articles/64 584-plastics-found-in-sea-bed-sharks (accessed on 24 July 2020).

Evans, Suzannah. 2015. Shark Week and the Rise of Infotainment in Science Documentaries. Communication Research Reports 32: $265-71$. [CrossRef]

Ferretti, Francesco, Boris Worm, Gregory L. Britten, Michael R. Heithaus, and Heike K Lotze. 2010. Patterns and ecosystem consequences of shark declines in the ocean. Ecological Letters 13: 1055-71. [CrossRef]

Fishman, Mark. 1980. Manufacturing the News. Austin: University of Texas.

Ford, Akkadia, and Zan Hammerton. 2020. Shifting the Anthropocentric Paradigms Embedded in Film and Classification (Ratings) Systems That Impact Apex Species. Animal Studies Journal 9: 147-91. Available online: https://ro.uow.edu.au/asj/vol9/iss2/7/ (accessed on 10 May 2021).

Francis, Beryl. 2012. Before and After Jaws: Changing Representations of Shark Attacks. The Great Circle 34: 44-61. Available online: https:/ /jstor.org/stable/23622226 (accessed on 22 August 2021).

Frank, Scott. 2003. Reel Reality: Science Consultants in Hollywood. Science as Culture 12: 427-69. [CrossRef]

Frisch, Ashley J., and Justin R. Rizzari. 2019. Parks for sharks: Human exclusion areas outperform no-take marine reserves. Frontiers in Ecology and the Environment 17: 145-50. [CrossRef]

Fuchs, Michael. 2018a. All Teeth and Claws: Constructing Bears as Man-Eating Monsters in Television Documentaries. European Journal of American Studies 13: 1-15. [CrossRef]

Fuchs, Michael. 2018b. Looking through the Beast's Eyes? The Dialectics of Seeing the Monster and Being Seen by the Monster in Shark Horror Movies Mise-en-Scène: The Journal of Film E Visual Narration 3: 1-15.

Gibbs, Leah. 2020. Agency in Human-Shark Encounter. EPE: Nature and Space, 1-22. [CrossRef]

Guerra, Ana Sofia. 2019. Wolves of the Sea: Managing human-wildlife conflict in an increasingly tense ocean. Marine Policy 99: 369-73. [CrossRef]

Hammerton, Zan, and Akkadia Ford. 2018. Decolonising the Waters: Interspecies Encounters Between Sharks and Humans. Animal Studies Journal 7: 270-303. Available online: http:/ / ro.uow.edu.au/asj/vol7/iss1/13 (accessed on 22 August 2021).

Hardiman, Nigel, Shelley Burgey, and Jia Shao. 2020. How Sharks and Shark-Human Interactions are Reported in Major Australian Newspapers. Sustainability 12: 2683. [CrossRef]

Heupel, Michelle R., Danielle M. Knip, Colin A Simpledorfer, and Nicholas K Dulvy. 2014. Sizing up the Ecological Role of Sharks as Predators. Marine Ecology Progress Series 495: 291-98. [CrossRef]

Huveneers, Charlie, Kirin Apps, Edgar E. Becerril-García, Barry Bruce, Paul A. Butcher, Aaron B. Carlisle, Taylor K. Chapple, Heather M. Christiansen, Geremy Cliff, Tobey H. Curtis, and et al. 2018. Future Research Directions on the Elusive White Shark. Frontiers in Marine Science 5: 1-15. [CrossRef]

Ingham, H. Rae Westbury, David L. Neumann, and Allison M. Waters. 2015. Empathy-related ratings to still images of human and nonhuman animal groups in negative contexts graded for phylogenetic similarity. Anthrozoös 28: 113-30. [CrossRef]

Ingram, David. 2000. Green Screen: Environmentalism and Hollywood Cinema. Exeter: University of Exeter Press.

International Shark Attack File. 2019. Yearly Worldwide Shark Attack Summary. Florida Museum. Available online: https://www. floridamuseum.ufl.edu/shark-attacks/yearly-worldwide-summary (accessed on 18 August 2020).

IUCN Red List. 2020. White Shark. Available online: https: / www.iucnredlist.org / search?query=white $\% 20$ shark\&searchType=species (accessed on 29 May 2020).

Jürgens, Uta Maria, and Paul M. W. Hacket. 2021. Wolves, Crows, and Spiders: An eclectic Literature Review inspires a Model explaining Humans' similar Reactions to ecologically different Wildlife. Frontiers in Environmental Science 9: 1-16. [CrossRef]

Katz, Brandon. 2019. Why Shark Movies Are Such Reliable Box Office Bets: A Deep Dive. Observer.com. July 6. Available online: https:/ / observer.com/2019/07/shark-movies-box-office-the-meg-the-shallows-47-meters-down-jaws (accessed on 20 July 2020).

Koven, Mikel J. 2007. Most haunted and the convergence of traditional belief and popular television. Folklore 118: 183-202. [CrossRef]

Kraterou, Aliki. 2021. Close Encounter: Shark Attacks to Be Renamed 'Negative Encounters' \& 'Bites' to Change Deadly Predators' Image, Say Scientists. The Sun. July 15. Available online: https://www.thesun.co.uk/news/15597242/shark-attacks-renamednegative-encounters-change-deadly-predators-image/ (accessed on 17 July 2020). 
Kueffer, Christoph, and Brendon M.H Larson. 2014. Responsible Use of Language in Scientific Writing and Science Communication. Bioscience 64: 719-24. [CrossRef]

Le Busque, Brianna, and Carla Litchfield. 2021. Sharks on film: An analysis of how shark-human interactions are portrayed in films. Human Dimensions of Wildlife, 1-7. [CrossRef]

Le Busque, Brianna, Philip Roetman, Jillian Dorrian, and Carla Litchfield. 2019. An analysis of Australian news and current affair program coverage of sharks on Facebook. Conservation Science and Practice 1: e111. [CrossRef]

Le Busque, Brianna, Jillian Dorrian, and Carla Litchfield. 2021a. The impact of news media portrayals of sharks on public perception of risk and support for shark conservation. Marine Policy 24: 1-8. [CrossRef]

Le Busque, Brianna, Philip Roetman, Jillian Dorrian, and Carla Litchfield. 2021b. People's fear of sharks: A qualitative analysis. Journal of Environmental Studies and Sciences, 1-8. [CrossRef]

Lerberg, Matthew. 2016. Jabbering Jaws: Reimagining Representations of Sharks Post-Jaws. In Screening the Nonhuman: Representations of Animal Others in the Media. Edited by Amber E. George and J. L. Schatz. Lanham: Lexington Books, pp. $33-46$.

Letessier, Tom, David Mouillot, Phil J. Bouchet, Laurent Vigliola, Marjorie C. Fernandes, Chris Thompson, Germain Boussarie, Jemma Turner, Jean-Baptiste Juhel, Eva Maire, and et al. 2019. Remote reefs and seamounts are the last refuges for marine predators across the Indo-Pacific. PLoS Biology 17: e3000366. [CrossRef]

Linné, Tobias. 2015. Tears, Connections, Action! Teaching Critical Animal and Media Studies. In Critical Animal and Media Studies. Edited by Núria Almiron, Matthew Cole and Carrie P. Freeman. London and New York: Routledge, Taylor and Francis Group, pp. 251-64.

Lucrezi, Serena, Suria Ellis, and Enrico Gennari. 2019. A test of causative and moderator effects in human perceptions of sharks, their control and framing. Marine Policy 109: 1-11. [CrossRef]

Lundén, Elizabeth Castaldo. 2012. Jaws: Creating the Myth of the Man-Eating Machine. Master's thesis, Stockholm University, Stockholm, Sweden.

Manfredo, Michael, Esmeralda G. Urquiza-Haas, Andrew W. Don Carlos, Jeremy T. Bruskotter, and Alia Dietsch. 2020. How anthropomorphism is changing the social context of modern wildlife conservation. Biological Conservation 241: 1-11. [CrossRef]

Martin, R. Aidan, Kim D. Rossmo, and Neil Hammershlag. 2009. Geographic profiling applied to track hunting patterns of white sharks in South Africa. Journal of Zoology 279: 111-18. [CrossRef]

McCagh, Christine, Joanne Sneddon, and Dominique Blache. 2015. Killing sharks: The media's role in public and political response to fatal human-shark interactions. Marine Policy 62: 271-78. [CrossRef]

Merskin, Debra L. 2015. Media Theories and the Crossroads of Critical Animal Media Studies. In Critical Animal and Media Studies. Edited by Núria Almiron, Matthew Cole and Carrie P. Freeman. Routledge Research in Cultural and Media Studies. London and New York: Taylor and Francis, pp. 11-25.

Merskin, Debra L. 2018. Seeing Species: Re-Presentations of Animals in Media E Popular Culture. New York: Peter Lang.

Metz, Anneke M. 2008. A Fantasy Made Real: The Evolution of the Subjunctive Documentary on US cable Science Channels. Television and New Media 9: 333-48. [CrossRef]

Mikos, Lothar. 2014. Analysis of Film. In The SAGE Handbook of Qualitative Data Analysis. Edited by Uwe Flick. London and Thousand Oaks: SAGE Publications, pp. 409-23.

Mikos, Lothar, Susanne Eichner, Elizabeth Prommer, and Michael Wedel. 2008. Involvement in 'The Lord of the Rings: Audience strategies and orientation. In Watching the Lord of the Rings: Tolkien's World Audiences. Edited by Martin Barker and Ernest Mathijs. New York: Peter Lang, pp. 111-29.

Miller, Suzanne. 2003. Summer of the Shark? Just When You Thought It Was Safe to Go into the Water...It Is. July 24. Available online: https: / / www.spiked-online.com/2003/07/24/summer-of-the-shark/ (accessed on 31 July 2020).

Muter, Bret A., Meredith L. Gore, Katie S. Gledhill, Christopher Lamont, and Charlie Huveneers. 2013. Australian and U.S. news media portrayal of sharks and their conservation. Conservation Biology 27: 187-96. [CrossRef]

Myrick, Jessica Gail, and Suzannah D. Evans. 2014. Do PSAs Take a Bite Out of Shark Week? The Effects of Juxtaposing Environmental Messages With Violent Images of Shark Attacks. Science Communication 36: 544-69. [CrossRef]

Neff, Christopher. 2015. The Jaws Effect: How movie narratives are used to influence policy responses to shark bites in Western Australia. Australian Journal of Political Science 50: 114-12. [CrossRef]

Neff, Christopher, and Robert Hueter. 2013. Science, policy, and the public discourse of shark attack: A proposal for reclassifying human-shark interactions. Journal of Environmental Studies in Science 3: 65-73. [CrossRef]

Nosal, Andrew P., Elizabeth A. Keenan, Philip A. Hastings, and Ayelet Gneezy. 2016. Hastings, and Ayelet Gneezy.The Effect of Background Music in Shark Documentaries on Viewers' Perceptions of Sharks. PLoS ONE 18: e0159279. [CrossRef] [PubMed]

Nyhus, Philip J. 2016. Human-wildlife conflict and coexistence. Annual Review of Environment and Resources 41: 143-71. [CrossRef]

Ordiz, Andrés, Richard Bischof, and Jon E. Swenson. 2013. Saving Large Carnivores, But Losing the Apex Predator? Biological Conservation 168: 128-33. [CrossRef]

Oxley, Douglas R., Arnold Vedlitz, and B. Dan Wood. 2014. The Effect of Persuasive Messages on Policy Problem Recognition. The Policy Studies Journal 42: 252-68. [CrossRef]

Parker, Garrett. 2016. How Much The Discovery Channel Makes During Shark Week. Money Inc. Available online: https://moneyinc. com/discovery-channel-shark-week/ (accessed on 19 August 2020). 
Parletta, Natalie. 2019. The Man Who Swims with Sharks. Interview of Charlie Huveneers. Cosmos Magazine. March 3. Available online: https:/ / cosmosmagazine.com/biology/the-man-who-swims-with-sharks/ (accessed on 6 June 2020).

Peace, Adrian. 2015. Sharks Aren't Criminals, But Our Fear Makes Us Talk as If They Are. The Conversation. January 26. Available online: https:/ / theconversation.com/sharks-arent-criminals-but-our-fear-makes-us-talk-as-if-they-are-36493 (accessed on 31 July 2020).

Pepin-Neff, Christopher. 2014. Shark Bite Statistics Can Lie, and the Result Is Bad Policy. The Conversation. January 15. Available online: https: / / theconversation.com/shark-bite-statistics-can-lie-and-the-result-is-bad-policy-21789 (accessed on 4 July 2020).

Pepin-Neff, Christopher, and Thomas Wynter. 2018a. Shark Bites and Shark Conservation: An Analysis of Human Attitudes Following Shark Bite Incidents in Two Locations in Australia. Conservation Letters 11: 1-8. [CrossRef]

Pepin-Neff, Christopher, and Thomas Wynter. 2018b. Reducing fear to influence policy preferences: An experiment with sharks and beach safety policy options. Marine Policy 88: 222-29. [CrossRef]

Petty, Richard E., and Duane T. Wegener. 1998. Attitude Change: Multiple Roles for Persuasion Variables. In Handbook of Social Psychology. Edited by Daniel Gilbert, Susan T. Fiske and Gardner Lindzey. New York: McGraw-Hill, pp. 323-90.

Pew Research Center for the People and the Press. 2009. Public Praises Science; Scientists Fault Public, Media. Washington, DC: Pew Center, Available online: https:/ / www.pewresearch.org/politics/2009/07/09/public-praises-science-scientists-fault-public-media / (accessed on 25 August 2021).

Pollo, Simone, Mariuccia Graziano, and Cristina Giacoma. 2009. The ethics of natural history documentary. Animal Behaviour 77: 1357-60. [CrossRef]

Qirko, Hector. 2017. Kinship appeals and conservation social marketing. Biodiversity and Conservation 26: 1009-27. [CrossRef]

Rees, William. 2020. Humanity's Plague Phase. Ecological Economics 169: 1-9. [CrossRef]

Rober, Mark. 2021. Producer. Shark vs. GoPro (Video). Broadcast on Shark Week 2021, Discovery+, July 12. Available online: https: / / www.youtube.com/watch?v=VS6tnF31zr4 (accessed on 15 July 2021).

Sabatier, Etienne, and Charlie Huveneers. 2018. Changes in Media Portrayal of Human-Wildlife Conflict During Successive Fatal Shark Bites. Conservation $\mathcal{E}$ Society 16: 338-50. Available online: https://www.jstor.org/stable/26500645?seq=1\#metadata_info_tab_ contents (accessed on 15 July 2020).

Schilds, Adam, Johann Mourier, Charlie Huveneers, Leila Nazimi, Andrew Fox, and Stephan T. Leu. 2019. Evidence for non-random co-occurrences in a white shark aggregation. In Behavioral Ecology and Sociobiology. vol. 73. [CrossRef]

Shiffman, David. 2018. Shark Scientists Explain What's Right and What's Wrong with Shark Week. Washington Post. July 24. Available online: https: / www.washingtonpost.com/news/animalia/wp/2018/07/24/shark-scientists-explain-whats-rightand-whats-wrong-with-shark-week/ (accessed on 30 July 2021).

Shiffman, David S., Sarah Joy Bittick, Madeline S Cashion, Sheila R. Colla, Laura E Coristine, Danielle H. Derrick, Elizabeth A. Gow, Catherine C. Macdonald, Mikayla More O'Ferrall, Melissa Orokbo, and et al. 2020. Inaccurate and Biased Global Media Coverage Underlies Public Misunderstanding of Shark Conservation Threats and Solutions. iScience 23: 101205. [CrossRef]

Silverstone, Roger. 1984. Narrative strategies in television science. Media, Culture and Society 6: 377-410. [CrossRef]

Simmons, Peter, and Michael Mehmet. 2018. Feeding Frenzy: Public Accuse the Media of Deliberately Fueling Shark Fear. The Conversation. June 22. Available online: https:/ / theconversation.com/feeding-frenzy-public-accuse-the-media-of-deliberatelyfuelling-shark-fear-95858 (accessed on 17 April 2021).

Sokal, Alan D. 2006. Pseudoscience and postmodernism: Antagonists or fellow travellers? In Archaeological Fantasies: How Pseudoarchaeology Misrepresents the Past and Misleads the Public. Edited by Garrett G. Fagan. London and New Yok: Routledge, pp. 286-361.

Solstice Media. 2019. Great Whites Shake Loner Tag. Medium. October 22. Available online: https://newsleads.medium.com/whitesharks-shake-loner-tag-7507146e167f (accessed on 14 November 2019).

Spielberg, Stephen. 1975. Director. Jaws (Film). Distributed by Universal Pictures. Available online: https://universalstudios.fandom. com/wiki/Jaws_(Film) (accessed on 15 May 2020).

Steffen, Will, Paul J. Crutzen, and John MacNeill. 2007. The Anthropocene: Are Humans Now Overwhelming the Great Forces of Nature? Ambio 36: 624-21. [CrossRef]

Stockton, Nick. 2016. The Ethics of Why You Should Definitely Watch Shark Week. Wired. June 29. Available online: https: //www.wired.com/2016/06/ethics-definitely-watchshark-week (accessed on 19 August 2019).

Sunstein, Cass R. 2002. Probability Neglect: Emotions, Worst Cases and Law. The Yale Law Journal 112: 61-107. Available online: https://www.jstor.org/stable/i270358 (accessed on 24 August 2021).

Tavares, Davi Castro, Jailson Fulgencio de Moura, Esteban Acevedo-Trejos, and Agostino Merico. 2019. Traits Shared by Marine Megafauna and Their Relationships With Ecosystem Functions and Services. Frontiers in Marine Science 6: 262. [CrossRef]

Van Dijk, Teun A. 1981. Episodes as Units of Discourse Analysis. In Analyzing Discourse: Text and Talk. Edited by Deborah Tannen. Washington, DC: Georgetown University Press, pp. 177-95.

Van Dijk, Teun A. 1988. News Analysis. Hillsdale: Lawrence Erlbaum.

Vidal, John. 2004. 'Dead Zones' Are Blamed for Rise in Shark Attacks. The Guardian. August 7. Available online: https: //www.theguardian.com/environment/2004/aug/07/conservationandendangeredspecies.internationalnews (accessed on 5 August 2019). 
Wallace, Paige. 2019. Phony Facts and Eco-media: Fake Nature and the Call for Widespread Media Literacy. Environmental Communication 13: 790-803. [CrossRef]

Whitley, Cameron Thomas, Linda Kalof, and Tim Flach. 2021. Using Animal Portraiture to Activate Emotional Affect. Environment and Behavior 53: 837-63. [CrossRef]

Williams, Linda. 1998. Melodrama revised. In Refiguring American Film Genres. Edited by Nick Browne. Berkeley: University of California Press, pp. 42-88.

Winters, Ben. 2008. Corporeality, Musical Heartbeats, and Cinematic Emotion. Music, Sound, and the Moving Image 2: 3-25. Available online: https: / / www.muse.jhu.edu/article/269080 (accessed on 23 August 2021).

Yuhas, Alan. 2021. Don't Call Them Shark Attacks, Scientists Say. The New York Times. July 20. Available online: https:/ /www.nytimes. com/2021/07/20/science/shark-attacks.html (accessed on 24 July 2021). 